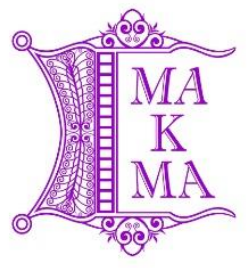

Majalah Kesehatan Masyarakat Aceh (MaKMA) http://ojs.serambimekkah.ac.id/index.php/makma

\title{
ANALISIS BEBAN KERJA PERAWAT DI INSTALASI RAWAT INAP RSUD SIDOARJO
}

\section{Hesma Wardhani Handarizki ${ }^{\bowtie}$, Rian Farandy Krisnugraha}

Fakultas Kesehatan Masyarakat Universitas Airlangga

${ }^{\square}$ Alamat Korespondensi: Jl. Dr. Ir. H. Soekarno, Mulyorejo, Kecamatan Mulyorejo, Kota Surabaya / hesma.wardhani.handarizki-2015@fkm.unair.ac.id / 082232296682

\begin{abstract}
ABSTRAK
Survei awal dari data sekunder RSUD Sidoarjo diperoleh bahwa perbandingan antara jumlah perawat dengan jumlah tempat tidur yang terpakai pada tahun 2009 hingga tahun 2011 melebihi standar yang ada dan mengalami peningkatan secara terus menerus. Hal tersebut dapat memicu beban kerja yang dirasakan perawat meningkat. Tujuan penelitian ini adalah menganalisis beban kerja perawat di instalasi rawat inap RSUD Sidoarjo. Metode yang digunakan yaitu deskriptif kuantitatif yaitu mengukur dan menggambarkan beban kerja perawat secara subyektif dan obyektif. Pengumpulan data dengan metode observasi dan self assement pada perawat di instalasi rawat inap RSUD Sidoarjo. Besar sampel penelitian yaitu 68 orang dengan teknik simple random sampling. Hasil penelitian didapatkan bahwa beban kerja subyektif tergolong sedang $(72,06 \%)$ dan beban kerja obyektif tergolong sedang $(55,88 \%)$. Kesimpulan penelitian ini yaitu beban kerja perawat di instalasi rawat inap RSUD Sidoarjo memiliki beban kerja yang cukup tinggi dan belum sesuai dengan standar yang ada. Saran dari peneliti yaitu melakukan evaluasi kinerja perawat dan memberikan reward kepada perawat terbaik serta melakukan pelatihan untuk meningkatkan kemampuan perawat.
\end{abstract}

Kata Kunci: Beban Kerja Obyektif, Beban Kerja Subjektif, Perawat 


\title{
NURSING WORKLOAD ANALYSIS IN THE INPATIENT INSTALLATION OF SIDOARJO DISTRICT HOSPITAL
}

\begin{abstract}
Preliminary survey from secondary data of Sidoarjo District Hospital was found that the comparison between the number of nurses and the number of beds used in 2009 to 2011 exceeded the existing standards and increased continuously. This can trigger the workload felt by nurses to increase. The purpose of this study was to analyze the nurses' workload in the inpatient installation of Sidoarjo District Hospital. The method used is descriptive quantitative that is to measure and describe the workload of nurses subjectively and objectively. Data collection by observation and self-assessment methods for nurses in the inpatient installation of Sidoarjo District Hospital. The size of the study sample is 68 people with simple random sampling technique. The results showed that the subjective workload was moderate $(72.06 \%)$ and the objective workload was moderate (55.88\%). The conclusion of this research is the workload of nurses in the inpatient installation of Sidoarjo District Hospital has a workload that is quite high and not in accordance with existing standards. Suggestions from researchers are evaluating nurses 'performance and giving rewards to the best nurses and conducting training to improve nurses' abilities.
\end{abstract}

Keywords: Nurses, Objective Workloads, Subjective Workloads, 


\section{PENDAHULUAN}

Menurut Undang-Undang Republik Indonesia Nomor 44 Tahun 2009 Tentang Rumah Sakit, Rumah sakit mempunyai tugas memberikan pelayanan kesehatan perorangan secara paripurna, yang memiliki fungsi penyelenggaraan pelayanan pengobatan dan pemulihan kesehatan sesuai dengan standar pelayanan rumah sakit, serta pemeliharaan dan peningkatan kesehatan perorangan ${ }^{[1]}$.

Rumah sakit merupakan salah satu organisasi yang menyediakan pelayanan jasa secara padat karya sehingga membutuhkan peranan dan fungsi Sumber Daya Manusia (SDM) yang sangat besar. Perawat merupakan sumber daya manusia terbanyak yang ada di rumah sakit. Seorang perawat dalam melakukan pekerjaannya pasti akan memiliki beban kerja tersendiri yang berbeda-beda. Beban kerja merupakan kemampuan (kesanggupan, kecakapan) yang dimiliki untuk menyelesaikan masalah, sehingga dapat berfungsi dan berproduksi secara proporsional sesuai dengan tugas dan fungsi yang dimiliki. Beban kerja seorang perawat di rumah sakit dapat dilihat dari rasio atau perbandingan antara jumlah perawat dengan jumlah tempat tidur yang terpakai.

Berdasarkan hasil survei awal di RSUD Sidoarjo menunjukkan bahwa ada peningkatan kunjungan rawat inap pada tahun 2011 sebesar $8,2 \%$. Terjadi peningkatan pula pada persentase BOR pada tahun 2011 sebesar 7,7\%. Sedangkan untuk jumlah tempat tidur dan perawat juga terjadi peningkatan pada tahun 2009 sampai tahun 2010, namun dari tahun 2010 sampai tahun 2011 tidak terjadi peningkatan jumlah tempat tidur maupun jumlah perawat. Berdasarkan Peraturan Menteri Kesehatan Nomor 340 Tahun 2010 Tentang Klasifikasi Rumah Sakit menyebutkan bahwa perbandingan antara jumlah perawat dengan jumlah tempat tidur yang terpakai yaitu 1:1 ${ }^{[2]}$. Sedangkan survei awal dari data sekunder RSUD Sidoarjo diperoleh bahwa perbandingan antara jumlah perawat dengan jumlah tempat tidur yang terpakai pada tahun 2009 yaitu 1:1,6 pada tahun 2010 yaitu $1: 1,9$ dan pada tahun 2011 yaitu 1:2,1. Berdasarkan hasil tersebut terlihat bahwa perbandingan antara jumlah perawat dengan jumlah tempat tidur yang terpakai pada tahun 2009 hingga tahun 2011 melebihi standar yang ada dan mengalami peningkatan secara terus menerus.

Pengukuran beban kerja dapat dilakukan dengan cara mengukur beban kerja subyektif dan beban kerja obyektif. Beban kerja subyektif yaitu ukuran yang dipakai dalam menjawab beban kerja yang dilakukan, perasaan kelebihan beban kerja, dan ukuran dari tekanan serta kepuasan kerja. Beban kerja subyektif meliputi persepsi terhadap beban fisik, mental, dan sosial. Sedangkan beban kerja obyektif kerja merupakan keadaan nyata yang ada di lapangan. Secara obyektif, beban kerja dilihat dari keseluruhan waktu yang dipakaii atau jumlah aktivitas yang dilakukan $^{[3]}$.

Penelitian Widayani (2017) menyatakan bahwa terdapat hubungan antara beban kerja dan kinerja perawat di ruang rawat inap kelas III RSUD Wates. Sebanyak 13 perawat $(14,3 \%)$ memiliki beban kerja tinggi dengan kinerja cukup dan 22 perawat $(24,2 \%)$ memiliki beban kerja yang rendah dengan kinerja yang baik [4]. Menurut Manuho et al. (2015) menunjukan bahwa sebagian besar $(88,9 \%)$ perawat yang bekerja di Irina C1 RSUP Prof. Dr. R. D. Kandou Manado memiliki beban kerja rendah dengan kinerja yang baik ${ }^{[5]}$. 
Beban kerja yang berlebihan dan tidak ditangani dengan baik akan mempengaruhi kinerja. Apabila kinerja tidak maksimal akan mempengaruhi kepuasan pelanggan. Kepuasan pelanggan merupakan salah satu profit center dari rumah sakit. Profit bagi rumah sakit tidak hanya didasarkan terhadap berapa jumlah keuntungan yang didapat tetapi kepuasan pelanggan juga menjadi salah satu manfaat atau keuntungan yang didapat oleh rumah sakit untuk menarik pelanggan atau

\section{METODE}

Jenis penelitian ini yaitu penelitian deskriptif kuantitatif. Penelitian ini mengukur dan menggambarkan beban kerja perawat secara subyektif dan obyektif. Lokasi penelitian yaitu di instalasi rawat inap RSUD Sidoarjo. Penelitian ini dilakukan pada bulan April - Juni 2012. Populasi penelitian yaitu semua perawat yang bekerja di instalasi rawat inap RSUD Sidoarjo sebanyak 204 orang. Sampel penelitian yaitu perawat yang bekerja di instalasi rawat inap RSUD Sidoarjo

\section{HASIL}

Beban kerja subyektif terbagi atas beban kerja fisik, sosial, dan mental. Hasil penelitian menunjukan bahwa perawat yang merasakan beban kerja fisik tinggi sebanyak 8 orang $(11,76 \%)$, merasakan beban kerja fisik sedang sebanyak 48 orang $(70,58 \%)$, dan merasakan beban kerja fisik rendah sebanyak 12 orang $(17,64 \%)$. Hasil penelitian menunjukan bahwa perawat yang merasakan beban kerja sosial tinggi sebanyak 3 orang $(4,41 \%)$, merasakan beban kerja sosial sedang sebanyak 41 orang $(60,29 \%)$, dan merasakan beban kerja sosial rendah sebanyak 24 orang $(35,29 \%)$. Hasil penelitian menunjukan bahwa perawat yang merasakan beban kerja mental tinggi sebanyak 4 orang pasien untuk datang atau mengunjungi pelayanan kesehatan tersebut kembali apabila pelanggan atau pasien tersebut menggalami gangguan kesehatan. Oleh karena itu, sangat penting bagi rumah sakit untuk menangani masalah beban kerja ini.

Berdasarkan permasalahan tersebut maka peneliti melakukan penelitian ini untuk menganalisis beban kerja perawat di instalasi rawat inap RSUD Sidoarjo.

sebanyak 68 orang yang tersebar di paviliyun sebanyak 5 orang; di rawat inap kelas I sebanyak 13 orang; di rawat inap kelas II sebanyak 23 orang; dan rawat inap kelas III sebanyak 27 orang. Teknik pengambilan sampel yaitu simple random sampling dengan metode undian. Pengumpulan data dilakukan dengan cara self assement dan mengamati saat reponden bekerja menggunakan lembar observasional. Selanjutnya hasilnya akan dikumpulkan, diuji secara, dan di analisis secara deskriptif.

$(5,80 \%)$, merasakan beban kerja mental sedang sebanyak 56 orang $(82,35 \%)$, dan merasakan beban kerja mental rendah sebanyak 8 orang $(11,76 \%)$. Dengan demikian secara keseluruhan perawat yang merasakan beban kerja subyektif tinggi sebanyak 7 orang (10,29\%), merasakan beban kerja subyektif sedang sebanyak 49 orang $(72,06 \%)$, dan merasakan beban kerja subyektif rendah sebanyak 12 orang $(17,65 \%)$ [Tabel.1].

Beban kerja obyektif perawat di tiap shift kerja berbeda-beda. Hasil penelitian menunjukan bahwa perawat yang bekerja di shift pagi merasakan beban kerja tinggi sebanyak 11 orang $(45,83 \%)$, merasakan beban kerja sedang sebanyak 10 orang $(41,67 \%)$, dan merasakan beban kerja rendah sebanyak 
3 orang (12,50\%). Hasil penelitian menunjukan bahwa perawat yang bekerja di shift sore merasakan beban kerja tinggi sebanyak 9 orang $(34,62 \%)$, merasakan beban kerja sedang sebanyak 15 orang $(57,69 \%)$, dan merasakan beban kerja rendah sebanyak 2 orang $(7,69 \%)$. Hasil penelitian menunjukan bahwa perawat yang bekerja di shift malam merasakan beban kerja tinggi sebanyak 4 orang $(22,22 \%)$, merasakan

\section{PEMBAHASAN}

\section{Beban Kerja Subyektif Perawat di Instalasi Rawat Inap RSUD Sidoarjo}

Beban kerja subyektif yang dirasakan perawat tergolong sedang. Beban kerja subyektif terdiri atas beban kerja fisik, beban kerja sosial, dan beban kerja mental. Beban kerja fisik yang dirasakan perawat di RSUD Sidoarjo tergolong sedang.

Hal tersebut dikarenakan beberapa faktor antara lain jumlah perawat tiap shift hanya 4 orang tiap lantai sedangkan jumlah pasien tiap lantai ada 20 pasien, jadi rata-rata setiap perawat menangani 5 pasien. Jumlah tersebut dirasa tidak seimbang menjadikan perawat cukup terbebani dengan tugas mereka dalam mendampingi pasien dalam kegiatan rehabilitatif. Selain itu perawat juga merasa terbebani terhadap perilaku pasien yang susah diatur, misalnya tidak mau minum obat, terus menerus mengeluh terhadap penyakitnya dan juga pasien anak yang sering rewel. Pada dasarnya perawat di setiap ruangan mengalami beban fisik yang hampir sama. Namun, ada satu ruangan yang memiliki beban fisik yang lebih berat yaitu pada ruangan paviliyun. Karena pada ruangan paviliyun semua kegiatan rehabilitatif dilakukan oleh perawat sedangkan diruangan tulip, teratai dan mawar dibantu dengan adanya dokter beban kerja sedang sebanyak 13 orang $(72,22 \%)$, dan merasakan beban kerja rendah sebanyak 1 orang $(5,56 \%)$. Dengan demikian secara keseluruhan perawat yang merasakan beban kerja obyektif tinggi sebanyak 24 orang $(35,29 \%)$, merasakan beban kerja obyektif sedang sebanyak 38 orang $(55,88 \%)$, dan merasakan beban kerja obyektif rendah sebanyak 6 orang $(8,82 \%)$ [Tabel.2].

muda yang bekerja praktek diruangan tersebut.

Hasil ini sesuai dengan penelitian Yudi et al. (2019) yang menyatakan bahwa beban kerja fisik perawat di IGD disebabkan oleh tidak seimbangnya jumlah perawat dengan pasien yang dilayani, tuntutan sebagai perawat IGD dan ICU yang harus melakukan kegiatannya secara cermat, cepat dan tepat serta kurangnya kerja sama antar $\operatorname{tim}^{[6]}$.

Beban kerja sosial yang dirasakan perawat di RSUD Sidoarjo tergolong sedang. Hal ini disebabkan oleh beberapa faktor antara lain adanya masalah dengan rekan kerja sesama perawat yang bekerja pada satu ruangan; Adanya perawat yang berhalangan hadir menyebabkan adanya penukaran shift yang menyebabkan berubahnya jadwal dinas; sulitnya berkomunikasi (menyampaikan pesan) dengan pasien yang memiliki daya tanggap lemah; Perawat harus mampu menyampaikan kondisi keadaan pasien baik maupun buruk kepada keluarga pasien; selain itu perawat juga harus dapat mengingatkan keluarga pasien atau penjenguk agar menjaga kebersihan dan tidak mengganggu pasien maupun pasien lain.

Hasil ini sesuai dengan penelitian Setiawan dan Wulandari (2016) yang menyebutkan bahwa tenaga farmasi merasakan beban kerja sosial berat 
karena adanya masalah dengan sesama rekan kerja saat melakukan pekerjaan ${ }^{[3]}$. Beban kerja mental yang dirasakan perawat di RSUD Sidoarjo tergolong sedang. Hal ini disebabkan oleh beberapa faktor antara lain perawat di instalasi rawat inap merasa terbebani secara mental terhadap tanggung jawabnya sebagai perawat di instalasi rawat inap; Limpahan tugas dari dokter kepada terhadap pasien yang kondisinya mengkhawatirkan dan membutuhkan penanganan yang intensif sehingga harus diawasi setiap saat; Kebijakan dan aturan yang dibuat oleh pihak Rumah Sakit juga bisa menjadi terbebani secara mental; Serta tugas yang monoton (sering dilakukan berulang) juga sering kali menyebabkan perawat merasa terbebani tidak hanya secara fisik, tetapi secara mental pun dapat membebani perawat.

Hasil tersebut sesuai dengan penelitian Aimi (2018) yang menyatakan bahwa beban kerja mental yang dirasakan perawat disebabkan karena perawat harus setiap saat mengawasi pasien yang kondisinya mengkhawatirkan dan perawat melakukan aktivitas atau tugas di ruang yang sama dengan pasien ${ }^{[7]}$.

\section{Beban Kerja Subyektif Responden di Instalasi Rawat Inap RSUD Sidoarjo}

Beban kerja obyektif yang dirasakan perawat tergolong sedang. Beban kerja obyektif dihitung dalam tiga shift kerja yang berbeda yaitu shift pagi, shift sore, dan shift malam. Beban kerja obyektif yang dirasakan perawat di RSUD Sidoarjo pada shift pagi tergolong tinggi.

Hal tersebut dikarenakan beberapa faktor antara lain jumlah perawat hanya 4 orang dengan tambahan tugas dari dokter saat visite pagi; Banyaknya uraian tugas asuhan keperawatan yang harus dikerjakan oleh perawat meliputi verbed atau pergantian seprei pada setiap tempat tidur yang ada pada ruangan, nebulizer dan TTV, SOAP (subjective objective analysis planning), dll sedangkan jam kerja tergolong singkat hanya 7 jam (420 menit) tiap harinya.

Hasil tersebut sesuai dengan penelitian Yudatama dan Haksama (2014) yang menyatakan bahwa perawat pada shift pagi memiliki beban kerja obyektif tinggi karena tugas langsung perawat shift pagi lebih banyak dibandingkan dengan shift yang lain selain itu pada shift pagi dokter lebih banyak melakukan visite ${ }^{[8]}$.

Beban kerja obyektif yang dirasakan perawat di RSUD Sidoarjo pada shift sore tergolong sedang. Hal ini disebabkan karena kegiatan asuhan keperawatan dependen dan Administrasi lebih besar namun asuhan keperawatan independen lebih rendah dari pada shift pagi. Artinya kebanyakan pasien yang ada sudah ditangani oleh perawat pada shift sebelumnya sehingga pada saat shift sore asuhan keperawatan independen menjadi lebih rendah dari shift sebelumnya tersebut.

Hasil tersebut sesuai dengan penelitian Aini (2018) yang menyatakan bahwa perawat rawat inap pada shift sore memiliki beban kerja obyektif tinggi karena perawat melanjutkan pekerjaan perawat shift pagi, pada shift sore perawat juga banyak mengeluh lelah dan pusing menghadapi keluhan pasien yang selalu mamanggil dan terkadang marah karena dokter lama datang ${ }^{[9]}$.

Beban kerja obyektif yang dirasakan perawat di RSUD Sidoarjo pada shift malam tergolong sedang. Hal ini disebabkan karenaa jam kerja yang cukup lama yaitu 10 jam (600 menit) dan rata-rata perawat yang bertugas pada shift malam yaitu berjumlah 3-4 orang tiap ruangan. Hal ini kemungkinan 
perawat menjadi terbebani secara mental akan tanggung jawab yang harus dilakukan demi menghindari adanya kejadian yang tidak diinginkan pada saat malam hari. Meskipun uraian tugas pada shift malam lebih dominan dengan kegiatan melihat kondisi pasien saja.

Hasil tersebut sesuai dengan penelitian Ramadhoni dan Pudjirahardjo (2016) yang menyatakan bahwa perawat rawat inap pada shift malam memiliki beban kerja obyektif tinggi karena kegiatan produktif tidak langsung dan kegiatan tidak produktif pada shift malam memiliki waktu yang lebih banyak daripada shift lainnya ${ }^{[10]}$.

\section{KESIMPULAN DAN SARAN}

Berdasarkan hasil penelitian ini maka dapat disimpulkan bahwa perawat di instalasi rawat inap RSUD Sidoarjo merasakan beban kerja kerja fisik sedang, beban kerja sosial sedang, dan beban kerja mental sedang. Jadi, beban kerja subyektif yang dirasakan perawat tergolong sedang. Sedangkan perawat yang berkerja di shift pagi merasakan beban kerja obyektif tinggi, perawat yang berkerja di shift sore merasakan beban kerja obyektif sedang, dan perawat yang berkerja di shift malam merasakan beban kerja obyektif sedang. Jado, beban kerja obyektif yang dirasakan perawat tergolong sedang. Secara keseluruhan maka beban kerja perawat di instalasi rawat inap RSUD

\section{DAFTAR PUSTAKA}

1. Undang-undang Republik Indonesia Nomor 44 Tahun 2009 Tentang Rumah Sakit. Jakarta: Republik Indonesia; 2009.

2. Peraturan Menteri Kesehatan Nomor 340 Tahun 2010 Tentang

\section{Keterbatasan Penelitian}

Penelitian ini melakukan perhitungan beban kerja dengan menggunakan metode time and motion study. Pada penelitian ini metode tersebut menggunakan alat self assement yang diberikan kepada perawat sehingga perawat dapat menilai dirinya sendiri. Hal tersebut berisiko perawat melakukan penilaian secara subyektif, sehingga lebih baik dilakukan langsung oleh peneliti melalui pengamatan sehingga diperoleh penilaian yang obyektif.

Sidoarjo memiliki beban kerja yang cukup tinggi dan belum sesuai dengan standar yang ada.

Berdasarkan hasil penelitian tersebut peneliti menyarankan pada RSUD memberikan pelatihan asuhan keperawatan sehingga dapat meningkatkan kemampuan perawat sehingga dapat menurunkan beban kerja yang dirasakan. RSUD Sidoarjo dapat melakukan evaluasi terhadap kinerja perawat dengan hasil evaluasi ini akan diperoleh berawat dengan kinerja terbaik, sehingga pihak RSUD Sidoarjo dapat memberikan reward kepada perawat tersebut sebagai bentuk apresiasi dan motivasi atas kinerja perawat. Serta RSUD Sidoarjo dapat membuat perencanaan untuk kegiatan rekrutmen mendatang agar dapat disesuaikan dengan kebutuhan.

Klasifikasi Rumah Sakit. Jakarta: Menteri Kesehatan; 2010.

3. Setiawan VB, Wulandari RD. Beban Kerja Subjektif dan Obyektif Tenaga Farmasi Rawat Jalan di Rumah Sakit. J Adm Kesehat Indones. 2016;4(1):2836. 
4. Widayani D. Hubungan Beban Kerja dengan Kinerja Perawat di Ruang Rawat Inap Kelas III RSUD Wates. Sekolah Tinggi Ilmu Kesehatan Jenderal Achmad Yani Yogyakarta; 2017.

5. Manuho E, Warouw H, Hamel R. Hubungan Beban Kerja dengan Kinerja Perawat dalam Pemberian Asuhan Keperawatan di Instalasi Rawat Inap C1 RSUP Prof. Dr. R. D. Kandou Manado. ejournal keperawatan. 2015;3(2):1-8.

6. Yudi D, Tangka JW, Wowiling F. Hubungan Beban Kerja Fisik dan Mental Perawat dengan Penerapan Patient Safety di IGD dan ICU RSU GMIM Pancaran Kasih Manado. e-journal Keperawatan. 2019;7(1):1-9.

7. Aimi NZ. Analisis Beban Kerja Mental dan Kebutuhan Tenaga
Kerja Perawat Bangsal Sumbodro dengan Metode NASA-TLX dan Workload Indicator Staffing Need (WISN) Studi Kasus Rumah Sakit Jiwa Daerah Surakarta. Universitas Muhammadiyah Surakarta; 2018.

8. Yudatama R, Haksama S. Beban Kerja Subjektif Perawat Intensive Care Unit. J Adm Kesehat Indones. 2014;2(3r):141-8.

9. Aini N. Hubungan Shift Kerja dengan Kelelahan Kerja pada Perawat di Instalasi Rawat Inap di Rumah Sakit Herna Medan Tahun 2018. J Jumantik. 2019;4(1):4556.

10. Romadhoni RD, Pudjirahardjo WJ. Beban Kerja Obyektif Tenaga Perawat di Pelayanan Rawat Inap Rumah Sakit. Jurnal. 2016;4(1):57-66. 


\section{LAMPIRAN}

Tabel [1]. Distribusi Frekuensi Beban Kerja Subyektif Responden di Instalasi Rawat Inap RSUD Sidoarjo

\begin{tabular}{lcccccccc}
\hline \multirow{2}{*}{ Beban Kerja Subyektif } & \multicolumn{2}{c}{ Tinggi } & \multicolumn{2}{c}{ Sedang } & \multicolumn{2}{c}{ Rendah } & \multicolumn{2}{c}{ Total } \\
& $\mathbf{n}$ & $\boldsymbol{\%}$ & $\mathbf{n}$ & $\boldsymbol{\%}$ & $\mathbf{n}$ & $\boldsymbol{\%}$ & $\mathbf{n}$ & $\boldsymbol{\%}$ \\
\hline Beban kerja fisik & 8 & 11,76 & 48 & 70,58 & 12 & 17,64 & 68 & 100,0 \\
Beban kerja sosial & 3 & 4,41 & 41 & 60,29 & 24 & 35,29 & 68 & 100,0 \\
Beban kerja mental & 4 & 5,80 & 56 & 82,35 & 8 & 11,76 & 68 & 100,0 \\
Beban kerja keseluruhan & 7 & 10,29 & 49 & 72,06 & 12 & 17,65 & 68 & 100,0 \\
\hline
\end{tabular}

Tabel [2]. Distribusi Frekuensi Beban Kerja Obyektif Responden Berdasarkan Kategori Beban Kerja di Instalasi Rawat Inap RSUD Sidoarjo

\begin{tabular}{lcccccccc}
\hline \multirow{2}{*}{ Beban Kerja Obyektif } & \multicolumn{2}{c}{ Tinggi } & \multicolumn{2}{c}{ Sedang } & \multicolumn{2}{c}{ Rendah } & \multicolumn{2}{c}{ Total } \\
& $\mathbf{n}$ & $\boldsymbol{\%}$ & $\mathbf{n}$ & $\boldsymbol{\%}$ & $\mathbf{n}$ & $\boldsymbol{\%}$ & $\mathbf{n}$ & $\boldsymbol{\%}$ \\
\hline Beban kerja shift pagi & 11 & 45,83 & 10 & 41,67 & 3 & 12,50 & 24 & 100,0 \\
Beban kerja shift sore & 9 & 34,62 & 15 & 57,69 & 2 & 7,69 & 26 & 100,0 \\
Beban kerja shift malam & 4 & 22,22 & 13 & 72,22 & 1 & 5,56 & 18 & 100,0 \\
Beban kerja keseluruhan & 24 & 35,29 & 38 & 55,88 & 6 & 8,82 & 68 & 100,0 \\
\hline
\end{tabular}

